\title{
How effective is the duration of breastfeeding on monosymptomatic enuresis nocturna?
}

\section{Anne sütü süresi monosemptomatik enürezis nokturnada ne kadar etkili?}

\author{
Kemal Gümüș ${ }^{1}$, Taner Kargı' ${ }^{2}$, Halil Ferat Öncel ${ }^{3}$ \\ 1 Balıklıgöl Government Hospital, Urology Clinic, Șanlıurfa, Turkey \\ 2 Bakırköy Dr. Sadi Konuk Training and Research Hospital, Department of Urology, İstanbul, Turkey \\ 3 Mehmet Akif Inan Training and Research Hospital, Department of Urology, Șanlıurfa, Turkey
}

Submitted (Geliş tarihi): 2021-09-13 Accepted (Kabul tarihi): 2021-11-10

\section{Correspondence / Yazıșma Kemal Gümüş Balıklıgöl Government Hospital, Urology Clinic, Şanlıurfa, Turkey Email: kemalag27@hotmail.com Tel: +905076159971}

\section{ORCID}

K.G. 0000-0001-9805-7387

T.K. 0000-0001-5874-3489

H.F.Ö. $\quad$ 0000-0003-4043-5597

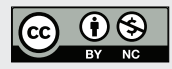

This work is licensed under a Creative Commons Attribution-NonCommercial 4.0 International License.

\section{Özet}

Amaç: $\mathrm{Bu}$ çalışmada, monosemptomatik enurezis nokturna üzerine anne sütü alımının süresi ve ilişkisini değerlendirmeyi amaçladık.

Gereç ve Yöntemler: Temmuz 2020- Eylül 2020 tarihleri arası üroloji kliniğimize başvuran 78 enürezis nokturna tanısı alan, 72 si kontrol grubu olan 150 çocuk çalışmaya dahil edildi. Anne sütünün süresi, evdeki çocuk sayısı, formül mama ile beslenme, ebeveyn eğitimi ve pasif sigara içiciliği soruldu.

Bulgular: Calıșmaya dahil edilen 150 hastanın yaş ortalaması 7,6 (5-10 yll) idi. Enürezis grubunu $36 \mathrm{kız}, 42$ erkek oluștururken, kontrol grubunu 36 kız, 36 erkek oluşturdu. Evdeki çocuk sayısı enürezis grubunda 7(3-10) iken, kontrol grubunda 5(4-8) idi. Her iki grup arasında anlamlı fark mevcuttu $(\mathrm{p}=0,008)$. Anne sütü ile beslenme süresi değerlendirildiğinde enürezis grubu ile kontrol grubu arasındaki anlamlı fark 18 ay olarak bulun$\mathrm{du}(\mathrm{p}=0,016)$. Formül mama ile beslenme enürezis grubu ve kontrol grubu arasinda fark yoktu $(p=0,599)$. Pasif sigara içiciliği ve ebeveynlerin eğitimi açısından her iki grup arasında fark yoktu.

Sonuç: Çocukluk çağında sık görülen rahatsızlıklardan birisi de enürezis nokturnadır. Yaşla birlikte devam etmesi çocuk da olumsuz birçok etki ortaya çıkarmaktadır. Çalışmamızda 18 aydan fazla emzirmeye devam edilirse enurezis nokturna görülme sıklığının azaldığı saptanmıştır. Ulaşılabilirliği kolay olan emzirmenin, çocukluk gelişiminin birçok yönü üzerindeki etkisine benzer şekilde, enürezis nokturna üzerinde olumlu bir etkisi vardır.

Anahtar Kelimeler: Enürezis nokturna, anne sütü, beslenme.
Abstract

Objective: This study aimed to evaluate the relationship and duration of breastfeeding in monosymptomatic enuresis nocturna.

Material and Methods: 150 children, 78 of whom were diagnosed with enuresis nocturna and 72 of whom were in the control group, who applied to our urology clinic between July 2020 and September 2020, were included in the study. The duration of breastfeeding, the number of children at home, formula feeding, parent education, and passive smoking were asked.

Results: The mean age of 150 patients included in the study was 7.6 (5-10 years). The enuresis group consisted of 36 girls and 42 boys, while the control group consisted of 36 girls and 36 boys. In comparison, the number of household members was 7(3-10) in the enuresis group, 5(4-8) in the control group. There was a significant difference between both groups $(\mathrm{p}=0.008)$. When the duration of breastfeeding was evaluated, the significant difference between the enuresis group and the control group was found to be 18 months $(p=0.016)$. There was no difference between the formula and feeding enuresis group and the control group $(\mathrm{p}=0.599)$. There was no difference between the two groups in terms of passive smoking and parental education.

Conclusion: One of the most common disorders in childhood is enuresis nocturna. Continuing with age has many negative effects on the child. Our study observed that the incidence of enuresis decreased if breastfeeding was continued for more than 18 months. Readily available breastfeeding positively affects enuresis nocturna, similar to its effect on many aspects of childhood development.

Keywords: Enuresis nocturna, breastfeeding, nutrition.

Cite As: Gümüş K, Kargı T, Öncel HF. How effective is the duration of breastfeeding on monosymptomatic enuresis nocturna?. New J Urol. 2022; 17(1):38-43. DOI: 10.33719/yud.2022;17-1-993791

The study was approved by Clinical Research Ethics Committee of Harran University, Turkey (Approval Number: 11/20, Approval Date: 15.06.2020).

All research was performed in accordance with relevant guidelines/regulations, and informed consent was obtained from all participants. 


\section{INTRODUCTION}

Monosymptomatic enuresis nocturna (MEN) is characterized by urinary incontinence that occurs only at night in children aged $>5$ years without any pathology in the urinary system (1). Although prevalence rates of $5 \%-15 \%$ have been reported for MEN, its prevalence in Turkey has been reported $20 \%-30 \%$ in schoolage children (2).

There is no definite consensus for the etiology of MEN; however, many factors, such as central nervous system development disorders, psychological and environmental factors, sleep disorders, genetic factors, passive smoking, the abnormal release of anti-diuretic hormone, some diseases of the urinary system (infections and anomalies), and other causes (polyuria, renal tubular diseases, neurological disorders, and parasites), may play a role in its etiology $(3,4)$. Thus, these factors indicate that neurological development is associated with MEN (5).

There is ample evidence that breast milk is very important for neurological development (6). As the nutrients required for neurological development are present in sufficient amounts in breast milk, adequate breast milk intake positively affects the mental and intellectual development of the infant (7). The role of polyunsaturated fatty acids in brain development function is important. Without a dietary source, infants must synthesize large amounts of docosahexaenoic acid and arachidonic acid to keep up with the needs of the developing brain. Without a dietary source, infants must synthesize large amounts of docosahexaenoic acid and arachidonic acid to keep up with the needs of the developing brain (8).

Therefore, we aimed to evaluate the effect of breastfeeding duration on enuresis frequency in children with MEN and its relationship with other factors.

\section{MATERIAL AND METHODS}

Seventy-eight patients diagnosed with primary MEN, aged 5-18 years, whose parents were not divorced, and who applied to the urology outpatient clinic between July 2020 and September 2020 with the complaint of nocturnal urinary incontinence were in- cluded in the study. Participants were informed about the study, and written consent was obtained from their parents. All data were reviewed retrospectively. A total of 72 healthy children who applied to the urology outpatient clinic for circumcision were included in the control group in the study. Patients with urinary tract infection, day and night voiding symptoms, hormonal disorders (diabetes insipidus, diabetes mellitus), and psychiatric diseases (attention deficit hyperactivity disorder, autism spectrum disorder, conduct disorder, anxiety, and mood disturbance) were excluded from the study. After detailed anamnesis and physical examination, patients were asked about their height, weight, number of children at home, how many months they had breastfed, whether they were fed with formula, history of passive smoking, and family education status. Those who had a history of being fed with a formula for any period in the first two years of life were classified as formula $(+)$, and those who did not were classified as formula (-).

Data were analyzed with SPSS software version 25.0 for Windows (SPSS Inc, Chicago, Illinois). The Kolmogorov-Smirnov test was used to verify that continuous variables were normally distributed. Normally distributed variables were expressed as mean \pm standard deviation $(\mathrm{SD})$, while non-normally distributed variables were expressed as median (minimum, maximum). The categorical variables are presented as percentages. Differences between the two groups were evaluated with students' unpaired t-test or the Mann-Whitney U test for normal or non-normal distribution parameters. The frequencies of nominal variables were compared using the Fisher's exact test or chi-square test.

\section{RESULTS}

The mean age of 150 patients included in the study was $7,6 \pm 1.8$ (5-10 years). The mean age of the enuresis group was $7,4 \pm 1.8$ years, and the mean age of the control group was $7.9 \pm 1.8$ years. No significant difference was found between the groups regarding age $(p=0.203)$ (Table 1). The enuresis group consisted of 36 girls and 42 boys, whereas the control group consisted of 36 girls and 36 boys. There was no significant difference 
between the groups in terms of gender $(\mathrm{p}=0.819)$. The mean body mass index (BMI) was $15,1 \mathrm{~kg} / \mathrm{m} 2$ in the enuresis group, $15.2 \mathrm{~kg} / \mathrm{m} 2$ in the control group. BMI was similar between the patient group and the control group $(\mathrm{p}=0.970)$. The median number of children at home was 7 (3-10) in the enuresis group, whereas it was 5 (4-8) in the control group; there was a signifi- cant difference between the groups ( $\mathrm{p}=0.008)$. When the duration of breastfeeding was evaluated, a significant difference of 18 months was found between the enuresis and control groups $(\mathrm{p}=0.016)$. There was no difference between the two groups regarding being fed formula ( $\mathrm{p}=0.599)$ nor in terms of passive smoking and parental education (Table 1).

Table 1. Comparison of patients and control groups

\begin{tabular}{|c|c|c|c|c|}
\hline & \multirow[t]{2}{*}{ All groups } & \multicolumn{2}{|c|}{ Enuresis Nocturna, \%(n) } & \multirow[t]{2}{*}{$\mathbf{P}$} \\
\hline & & $(+)$ & $(-)$ & \\
\hline Household members & $6(3,10)$ & $7(3,10)$ & $5(4,8)$ & $0.008^{\star}$ \\
\hline Breast feeding & & & & $0.016^{*}$ \\
\hline$<18$ months & $58.7(88)$ & $71.8(56)$ & $44.4(32)$ & \\
\hline$>18$ months & $41.3(62)$ & $28.2(22)$ & $55.6(40)$ & \\
\hline Formula feeding & & & & 0.599 \\
\hline Formula feeding + & $58.7(88)$ & $61.5(48)$ & $55.6(40)$ & \\
\hline Formula feeding - & $41.3(62)$ & $38.5(30)$ & $44.4(32)$ & \\
\hline Pasive smoker & & & & 0.525 \\
\hline Pasive smoker + & $57.3(86)$ & $53.8(42)$ & $61.1(44)$ & \\
\hline Pasive smoker - & $42.7(64)$ & $46.2(36)$ & $38.9(28)$ & \\
\hline Maternal Education & & & & 0.416 \\
\hline Educated & $50.7(76)$ & $46.2(36)$ & $55.6(40)$ & \\
\hline Uneducated & $49.3(74)$ & $53.8(42)$ & $44.4(32)$ & \\
\hline
\end{tabular}

\section{DISCUSSION}

Breastfeeding has many benefits for the mother and infant. Breast milk is the best food for the infant as it contains all the nutrients needed for healthy growth and development (9). Breastfeeding supports the child's neurological development because of the lipid structure in the constituents of milk. Breastfeeding not only serves the purpose of feeding but is also a special psychophysical stimulant for the mother and infant. During breastfeeding, the mother provides the infant with a feeling of warmth, security, and protection. If emotional bonds are established securely in childhood, undesirable behaviors, such as addiction and involvement in crime, can be prevented (10). Girard et al. found that difficulties in establishing emotional bonds and attention deficits were more common in breastfed children for $<12$ months (11). Kwok et al. reported that breastfeeding for $<3$ months was associated with worse behavior and lower self-esteem. Psychogenic factors play a role in the etiology of MEN in a manner similar to stress (12). Furthermore, neurodevelopmental delays were observed in children with MEN (13). In the literature, the relationship between MEN and breastfeeding is still unclear. In a cross-sectional study by Gümüş et al., different clinical factors that played a role in childhood bedwetting were evaluated, and no difference was found between patients with and without enuresis, with reference to breastfeeding rates in the first four months after birth (14). In a study conducted on 1212 school-age children, Sristava et al. reported that enuresis nocturna was significantly more common in children who were not exclusively breastfed until the age 
of 6 months (15). Barone et al. compared children with enuresis with a control group and demonstrated that breastfed for $>3$ months had a protective effect against bedwetting (16). In a recent observational case-control study involving 200 subjects (children and adolescents) aged 6 to 14 years, Oliviera et al. reported that a breastfeeding duration of $<4$ months was strongly associated with MEN (17). In the present study, when breastfeeding durations were compared, a duration of 18 months was found to be significant. The prevalence of enuresis was found to be significantly higher in those who were breastfed for $<18$ months compared with that in those who were breastfed for $>18$ months $(\mathrm{p}<0.05)$. In terms of child development, the World Health Organization recommends breastfeeding for 24 months (18). In line with this recommendation and the results of the present study, we believe that the prevalence of MEN can be reduced by prolonging the duration of breastfeeding.

Passive smoking in children is an extremely important public health problem directly associated with many childhood diseases (19). Previous studies have shown that passive smoking leads to impaired respiratory symptoms, allergic diseases, and sleep quality in children (20). Studies on adult female patients with secondary enuresis nocturna reported that smoking negatively affects bladder function and that smoking was identified as a risk factor for enuresis nocturna (21). A recent study on children with MEN demonstrated that the response to desmopressin treatment was lower in those exposed to cigarette smoke (22). Although there is scientific evidence on the relationship between MEN and exposure to cigarette smoke, no difference was found between the enuresis and control groups in terms of passive smoking in the present study.

MEN may be associated with nocturnal urine production due to insufficient vasopressin hormone formation during sleep (23). Breastfeeding increases early neuronal maturation and visual acuity, which may be important in driving the normal circadian rhythm and establishing normal neuronal pathways (24). Kalo et al. showed that breastfeeding increases the development of nocturnal continence and reduces this possibility as an incidental finding (25). We also obtained similar results in the present study.
Many studies in the literature demonstrate that familial factors, such as low socioeconomic status, low educational level of parents, family size, and birth order are associated with MEN (26). On the other hand, Spee-van der Wekke et al. reported that the parents' education level was not associated with the prevalence of MEN (27). In the present study, we were unable to find a relationship between parental education level and MEN.

Studies are reporting that the prevalence of enuresis nocturna increases in extended families (28). The present study found that the prevalence of enuresis nocturna increased in families with many children at home.

The most important limitation of the present study was the large time difference between breastfeeding, the onset of enuresis, and when the survey was conducted. The data used in the study were based on the parents' statements, and those who had difficulty remembering and those who could not completely remember necessary details were excluded from the study.

\section{CONCLUSION}

MEN is an important public health problem common in childhood and causes considerable distress for children and their parents. The present study found that the prevalence of MEN decreased in children who were breastfed for $>18$ months. Like many of its effects on childhood development, breastfeeding, an easy and convenient feeding method for mothers, also positively affects MEN. There is a need for further prospective multicenter studies on this subject with larger patient series.

\section{Conflict of interest}

The authors declare to have no conflicts of interest.

\section{Financial Disclosure}

The authors declared that this study has received no financial support.

\section{Informed Consent}

Informed consent was obtained from all individual participants included in the study. 


\section{Ethical Approval}

The study was approved by Clinical Research Ethics Committee of Harran University (Approval Number: 11/20, Approval Date: 15.06.2020) and written informed consent was received from all participants. The study protocol conformed to the ethical guidelines of the Helsinki Declaration.

\section{Author Contributions}

Conception and design; KG, Data acquisition; KG, Data analysis and interpretation; TK, HFÖ, Drafting the manuscript; KG, Critical revision of the manuscript for scientific and factual content; TK, HFÖ, Statistical analysis; KG, Supervision; TK, HFÖ.

\section{REFERENCES}

1. Kefi A, Tekgül S. Nocturnal enuresis. Turkish Journal of Urology 2006; 32:99-105.

2. Neyzi O, Ertuğrul T, Eksi A. Psychosocial development and problems, psychological development of the child, Enuresis, Pediatri. Istanbul: Nobel Medical Publishers, 2002; 1420-1421.

3. Okur M, Ruzgar H, Erbey F, Kaya A. The evaluation of children with monosymptomatic nocturnal enuresis for attention deficit and hyperactivity disorder Int J Psychiatry Clin Pract. 2012; 1:229-232.

4. Safarinejad MR. Prevalence of nocturnal enuresis, risk factors, associated familial factors and urinary pathology among school children in Iran. J Pediatr Urol 2007; 3:443-452.

5. Ergüven M, Celik Y, Deveci M, Ylldız N. Etiological risk factors in primary nocturnal enuresis. Turkish Archives of Pediatrics. 2004; 39:83-87.

6. Auestad N, Scott DT, Janowsky JS, Jacobsen C, Carroll $\mathrm{RE}$, Montalto MB, et al. Visual, cognitive, and language assessments at 39 months: a follow-up study of children fed formulas containing long-chain polyunsaturated fatty acids to 1 year of age. Pediatrics. 2003; 112:177-183.

7. H Giray. Anne sütü ile beslenme. Sürekli Tıp Eğitimi Dergisi, 2004.

8. Reynolds A. Breastfeeding and Brain Development. Pediatr Clin North Am. 2001; 48(1):159-71.

9. Brummelte S, Galea L.A. Postpartum depression: Etiology, treatment and consequences for maternal care. Horm. Behav. 2016; 77:153-166.
10. Štefica Mikšić, Boran Uglešić, Jelena Jakab, Dubravka Holik, Andrea Milostić Srb, Dunja Degmečić. Positive Effect of Breastfeeding on Child Development, Anxiety, and Postpartum Depression. Int J Environ Res Public Health. 2020; 17(8): 2725.

11. Girard LC, Farkas C. Breastfeeding and behavioural problems: Propensity score matching with a national cohort of infants in Chile BMJ Open. 2019; 15(9): e025058.

12. Kwok MK, Leung GM, Schooling CM. Breast feeding and early adolescente behaviour, self-esteem and depression: Hong Kong's 'Children of 1997' birth cohort. Arch Dis Child. 2013; 98:887-894.

13. Von Gontard A, Schmelzer D, Seifen S, Pukrop R. Central nervous system involvement in nocturnal enuresis: evidence of general neuromotor delay and specific brainstem dysfunction. J Urol. 2001; 166:2448-2451.

14. Gümüş B, Vurgun N, Lekili M, Işcan A, Müezzinoğlu T, Büyuksu C. Prevalence of nocturnal enuresis and accompanying factors in children aged 7-11 years in Turkey. Acta Pediatr. 1999; 88:1369-1372.

15. Srivastava S, Srivastava KL, Shingla S. Prevalence of monosymptomatic nocturnal enuresis and its correlates in school going children of Lucknow Indian J Pediatr. 2013; 80(6):488-491.

16. Barone JG, Ramasamy R, Farkas A, Lerner E, Creenan E, Salmon D, et al. Breastfeeding during infancy may protect against bed-wetting during childhood. Pediatrics. 2006; 118:254-259.

17. Oliveira DM, Dahan P, Ferreira DF, Oliveira LF, Paula LI, Figueiredo AA, et al. Association between exclusive maternal breastfeeding during the first 4 months of life and primary enuresis. J Pediatr Urol. 2016; 12: e1-e6.

18. World Health Organization. Infant and young child nutrition. Global strategy on infant and young child feeding. Report by the secretariat. April 16, 2002.

19. Arguder E, Abuzaina O, Bakır H, Karalezli A, Hasanoglu H. Awareness of the Patients and Their Relatives About the Health Problems Occurred by Passive Smoking. Ankara Med J. 2019; 1:213-225.

20. Vanker A, Gie RP, Zar HJ. The association between environmental tobacco smoke exposure and childhood respiratory disease: a review. Expert Rev Respir Med. 2017 ; 11(8): 661. 
21. Enki D, Drake MJ, Hashim H. The functional effects of cigarette smoking in women on the lower urinary tract. Urol Int 2015; 95(4):478.

22. Kaya Aksoy G, Semerci Koyun N, Doğan ÇS. Does smoking exposure affect response to treatment in children with primary monosymptomatic nocturnal enuresis? J Pediatr Urol. 2020; 16(1):47.e1-47.e6.

23. Hamed SA, Fawzy M, Hamed EA. Behavioral problems in children with primary monosymptomatic nocturnal enuresis. Compr Psychiatry. 2021; 104:152208.

24. Devitt H, Holland P, Butler R, et al Plasma vasopressin and response to treatment in primary nocturnal enuresis Archives of Disease in Childhood 1999; 80:448-451.

25. Makrides M, Neumann M,Simmer K,Pater J,Gibson R Are long-chain polyunsaturated fatty acids essential nutrients in infancy? Lancet 1995; 345:1463-1468.
26. Kalo BB, Bella $\mathrm{H}$ Enuresis: prevalence and associated factors among primary school children in Saudi Arabia. Acta Paediatr Scand 1996; 85:1217-1222.

27. Cher TW, Lin GJ, Hsu KH. Prevalence of nocturnal enuresis and associated familial factors in primary school children in Taiwan. J Urol 2002; 168:1142e6.

28. Spee-van der Wekke J, Hirasing RA, Meulmeester JF, Radder JJ. Childhood nocturnal enuresis in the Netherlands. Urology 1998; 51:1022e6.

29. Eapen V, Mabrouk AM. Prevalence and correlates of nocturnal enuresis in the United Arab Emirates. Saudi Med J. 2003; 24(1):49-51. 